\title{
TUBERCULOSIS OF THE FEMORAL NECK AND GREATER TROCHANTER
}

\author{
R. T. Ahern, Ascot, England \\ From the Heatherwood Orthopaedic Hospital, Ascot
}

TUBERCULOSIS OF THE FEMORAL NECK

During the nine years up to the end of 1956 six cases of tuberculosis of the femoral neck have been treated at Heatherwood Orthopaedic Hospital. This relatively uncommon lesion has formed less than 0.5 per cent of all the skeletal tuberculosis treated.

Many authors have regarded tuberculosis of the femoral neck as the primary site of bone involvement in tuberculosis of the hip joint, and have included it in reviews of that lesion. This is not surprising because, in the absence of chemotherapy, most of these lesions have extended into the hip joint to cause a pan-arthritis irrespective of the method of treatment.

Bergman (1930) described a good result in a single case with a juxta-epiphysial lesion treated conservatively. He also quoted four cases of Waldenstrom's with satisfactory results two years after treatment by excision. Logroscino (1936) gave a useful classification of lesions of the femoral neck. He divided these on a regional basis into four types of focus: 1) cervicodiaphysial; 2) juxta-epiphysial; 3) bulbo-metaphysial; 4) metaphysial subtrochanteric. He claimed good results in six of fifteen patients treated conservatively and stated that a pan-arthritis followed excision.

Hatcher and Phemister (1937), in a review of tuberculosis of the hip joint in seventy children, stated that the juxta-epiphysial region of the femoral neck was the commonest site of primary bone involvement and was affected in fourteen children. The hip joint remained intact in only two of these patients. Cholmeley (1939) reported fifty-five patients with extra-articular lesions. The disease spread to involve the hip in eleven out of twelve patients treated surgically and forty out of forty-three treated conservatively. Ponseti (1948) referred to seven out of thirty-one patients with para-articular foci. Four were in the ilium and three in the femoral neck. The disease spread to involve the hip in all seven patients irrespective of the method of treatment.

Dobson (1951), in a review of 320 cases of tuberculosis of the hip, stated that primary bone involvement of the femoral neck occurred in only fifteen patients. Wilkinson (1953) stated that a tuberculous infection of the ends of long bones was usually accompanied by involvement of the synovial membrane. He claimed satisfactory results in nineteen of twentythree patients treated by curettage and partial synovectomy under antibiotic cover.

\section{CLINICAL REVIEW}

Three of the six patients under review were treated conservatively. Two of these patients made a complete recovery, but radiologically it was shown that healing was very slow. The third patient treated conservatively developed tuberculous arthritis with destruction of the joint two and three-quarter years later. The remaining three patients were treated by excision of the focus and chemotherapy. These three patients received streptomycin combined with para-amino-salicylic acid (PAS) or izo-nicotinic acid hydrazide (INH) or both. All three made a rapid and complete recovery. The improvement noted radiologically at the end of three months was most convincing.

\section{CASE REPORTS}

Case 1-Girl aged three years. A slight limp and discomfort in the region of the right hip joint had been noticed for fourteen months before her admission. There was slight restriction of movement. Radiographs revealed a lesion of the metaphysial subtrochanteric region with involvement of the 


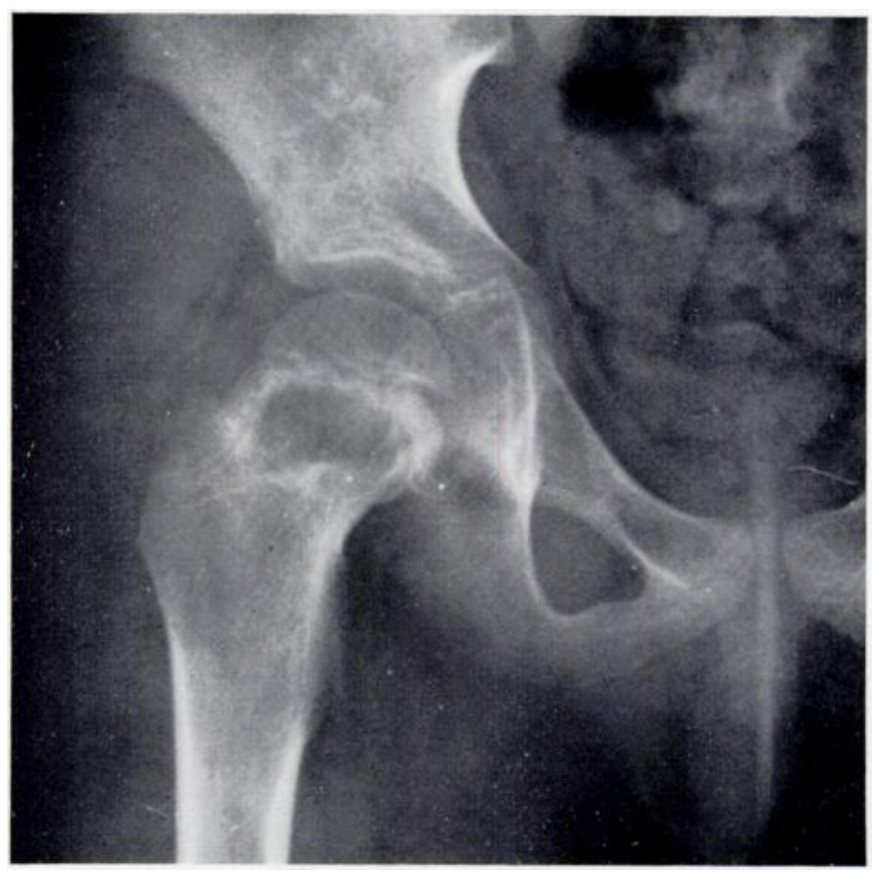

FIG. 1

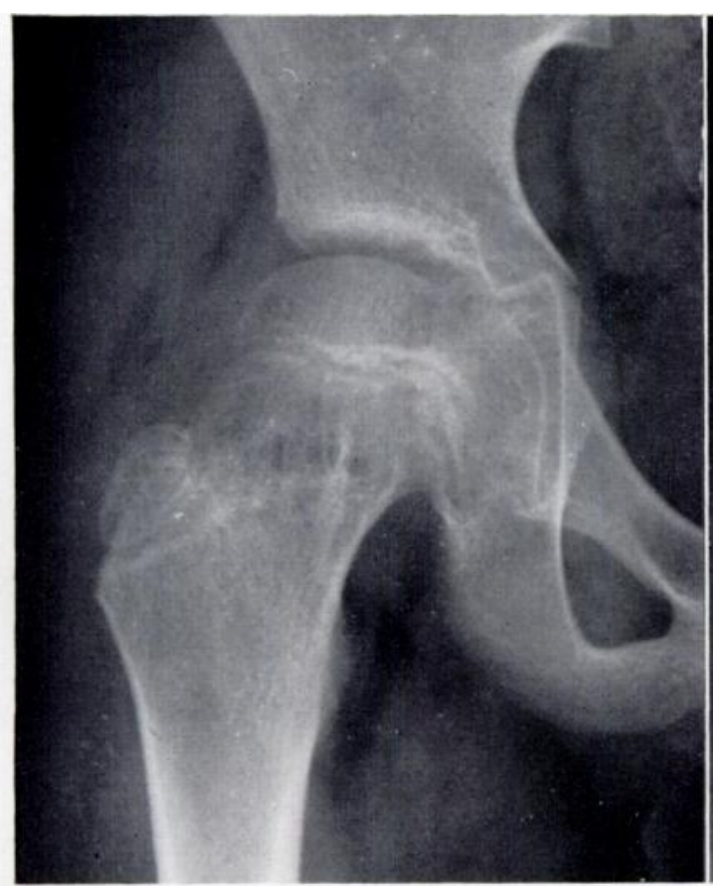

FIG. 2

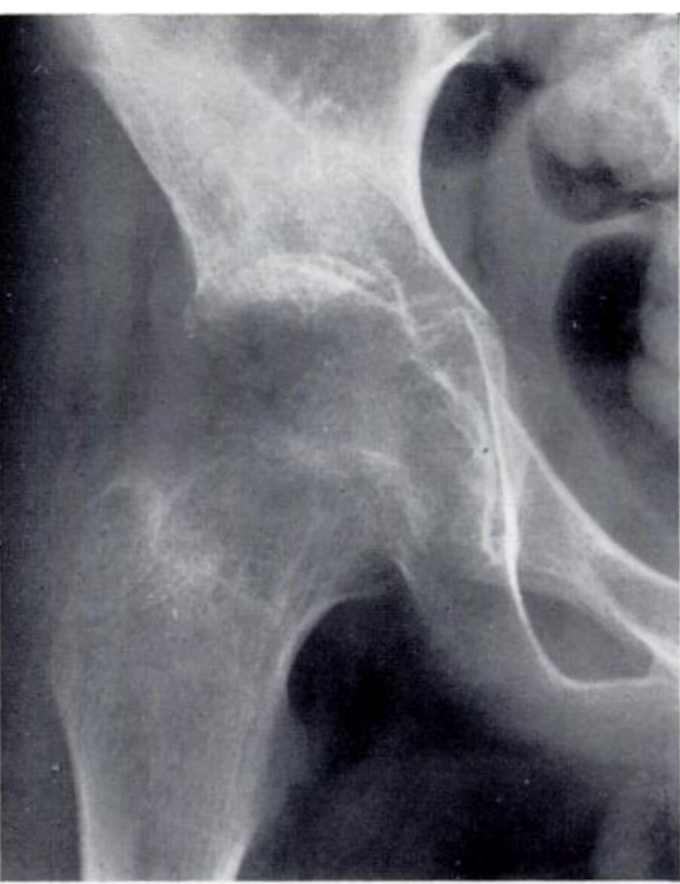

Fig. 3

Case 3. Figure 1-Radiograph showing large juxta-epiphysial lesion of femoral neck. Figure 2-Two years later: the lesion appears healed. Figure 3-Two and a half years later still: the hip joint is involved.

vol. $40 \mathrm{~B}$, No. 3, AUGUST 1958

C 
inner part of the trochanteric epiphysis. She was treated by bed rest and immobilisation in plaster for twelve months. Radiographs then showed recalcification and partial obliteration of the focus. She regained full movement. The focus could still be seen in radiographs taken three years after discharge. When she was last seen nearly seven years after treatment normal function was present at the hip.

Case 2-Girl aged five years. This patient had been seen and investigated elsewhere for discomfort and slight limp at the left hip, and had already undergone eight months' immobilisation in plaster for a lesion of the left femoral neck. There was slight restriction of movement at the left hip, and radiographs revealed an extensive lesion of the cervico-diaphysial region. She was treated by bed rest and immobilisation in plaster for a further fourteen months. Radiographs then showed that the lesion was well localised, with good surrounding calcification. She was allowed up in a weight-relieving caliper which was worn for a further ten months. Full movement was rapidly regained. Radiographs taken six years after discharge showed complete obliteration of the focus. When she was last seen six and a half years after treatment normal function was present at the hip.

Case 3-Boy aged eight years. Discomfort and slight limp at the right hip joint had been noticed for seven months, and movements at the hip joint were restricted to half the normal range. Radiographs revealed an extensive juxta-epiphysial lesion (Figs. 1 to 3). The boy was treated by bed rest and immobilisation in plaster for fifteen months. Radiographs then showed apparent healing with obliteration of the cavity but, clinically, movement was still only through half the normal range. Activity was encouraged, but movement did not improve. Radiographs taken nine months later showed further improvement. Two and three-quarter years later there was increasing pain and stiffness, with flexion-adduction deformity, and radiographs then revealed involvement of the hip joint.

Case 4-Boy aged three years. Discomfort and slight limp at the left hip joint had been noticed for three months, and there was slight restriction of movement. Radiographs revealed an extensive lesion of the femoral neck extending from the trochanteric region across the epiphysial line to involve the inner and lower part of the capital epiphysis (Fig. 4). The diagnosis was supported histologically by an external iliac gland biopsy. No improvement was noted either clinically or radiologically after two months' immobilisation in plaster and chemotherapy. Curettage of the focus through a subtrochanteric approach was performed.

Operation-A large sequestrum was removed. The lesion was very vascular and no pus was encountered. The cavity communicated with the hip joint. No bone chips were used. The cavity was dusted with streptomycin, and the wound closed.

Progress-There was immediate and striking improvement in the patient's general condition (Fig. 5). Immobilisation was continued for three months, and chemotherapy for a total of three and a half months, including the period before operation. Radiographs showed excellent recalcification and obliteration of the cavity (Figs. 6 and 7). Full movement was present at the hip and the patient rapidly regained his activity. The total period of observation was four and a half years, and normal function was present at the left hip joint.

Case 5-Boy aged nine years (Fig. 3). This child developed miliary tuberculosis and proved meningitis at the age of two and three-quarter years, and made a complete recovery after six months' intrathecal and intramuscular streptomycin. Two and three-quarter years later he developed tuberculous arthritis of the left hip and again made a complete recovery with conservative treatment for a year, with a four months' course of streptomycin. He was readmitted over two years later for investigation of discomfort and slight restriction of movement at the right hip which had been present for a month. Radiographs revealed an early lesion of the outer part of the femoral neck (Fig. 8). He was treated by immobilisation and chemotherapy, but radiographs taken five weeks later showed rapid destruction of the femoral neck (Fig. 9). Curettage of the focus through a Smith-Petersen approach was performed.

Operation-The lesion was still separated from the joint by a thin periosteal layer. A large sequestrum with much debris was removed from a large cavity involving three-quarters of the substance of the femoral neck. Erosion had extended to the cartilage of both the capital and trochanteric epiphysial lines. No bone chips were used. The cavity was dusted with streptomycin powder and the wound closed.

Progress-Immobilisation was continued for three months and chemotherapy for a total of four months including the time before operation. Radiographs then showed marked improvement in density and definition, with filling in of the cavity (Fig. 10). Full movement was present. The patient has been observed for two and a half years, and normal function is present at the hip. Culture and guinea pig inoculation of material from the bone cavity were negative. 


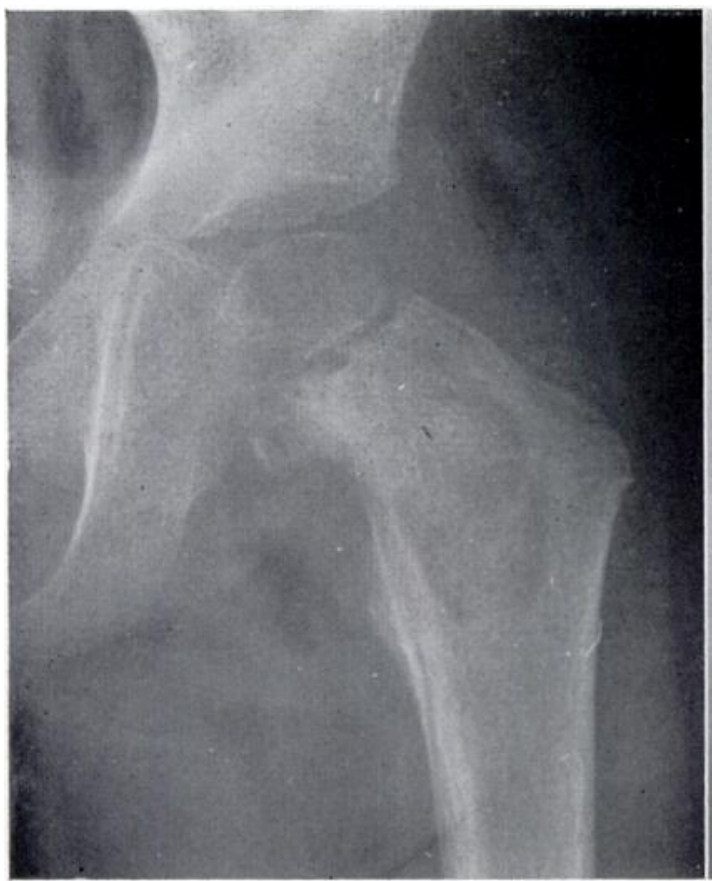

Fig. 4

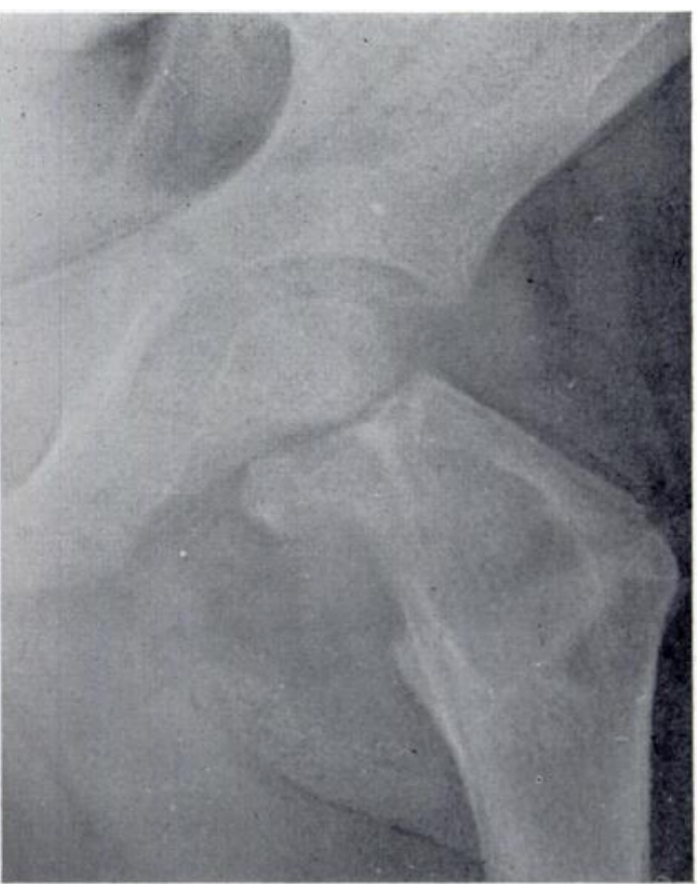

FIG. 5

Case 4. Figure 4-Radiograph showing large focus in femoral neck with sequestration and involvement of the lower part of the capital epiphysis. Figure 5-Appearance after operation, a month later.

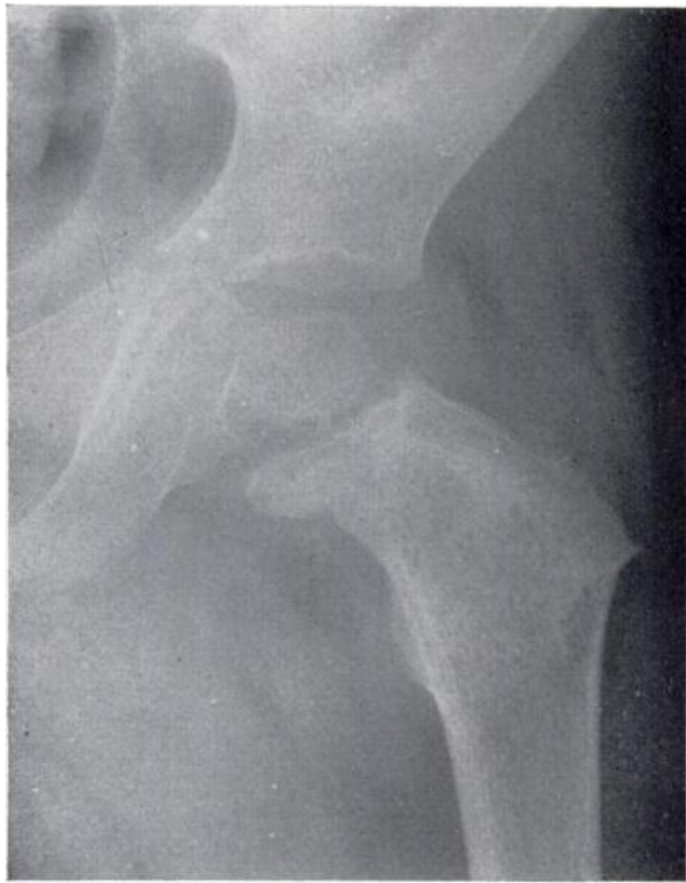

FIG. 6

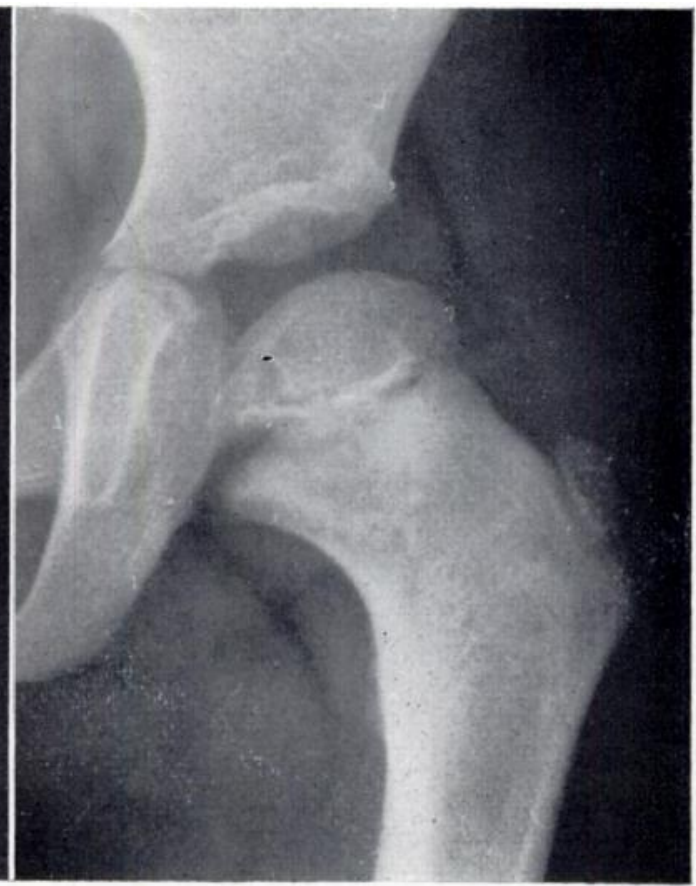

Fig. 7

Case 4. Figure 6-Three months after operation, showing excellent recalcification and obliteration of cavity. Figure 7-Appearance one year and seven months after operation.

Vol. $40 \mathrm{~B}$, No. 3, AUgust 1958 


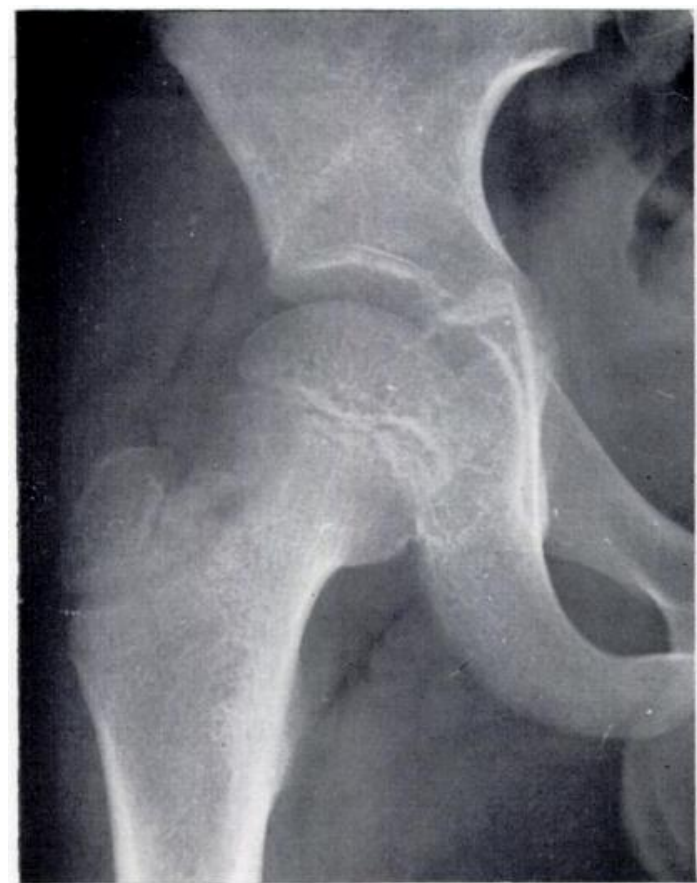

FIG. 8

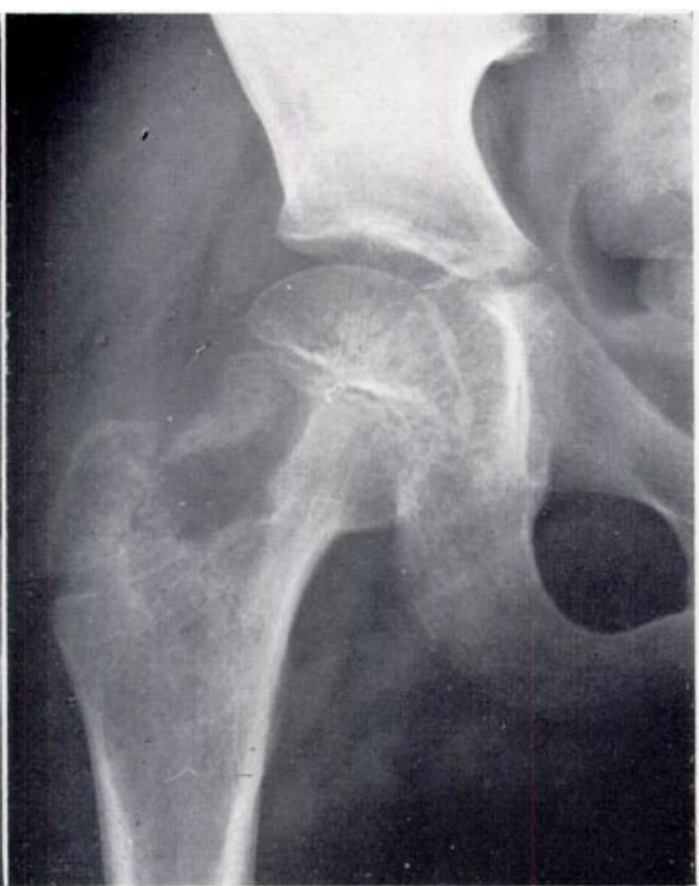

Fig. 9

Case 5. Figure 8-Radiograph showing an early lesion of the outer portion of the femoral neck. Figure 9Five weeks later, showing sequestration and rapid spread of lesion.

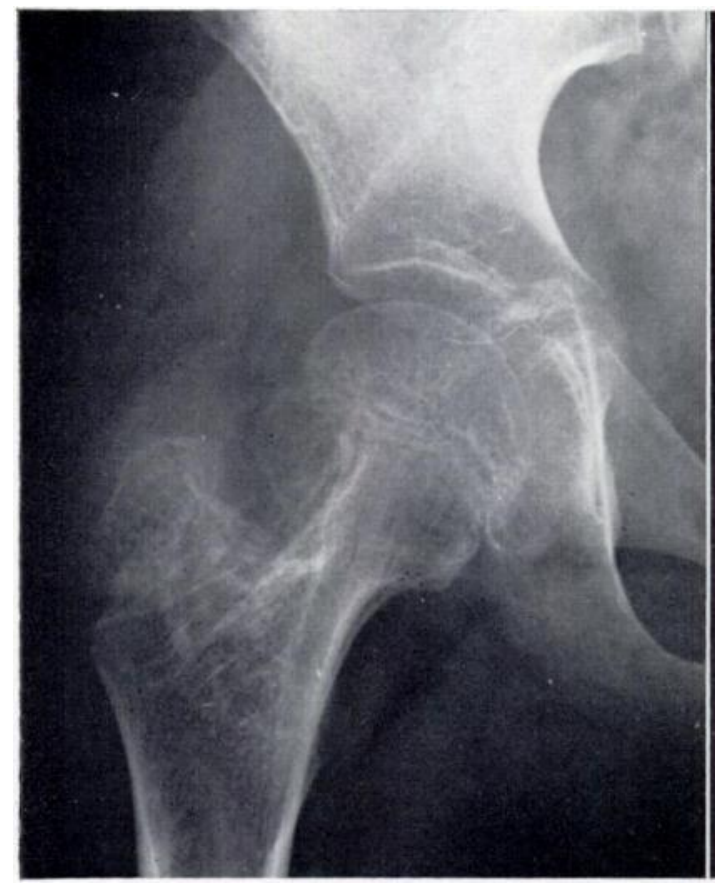

FIG. 10

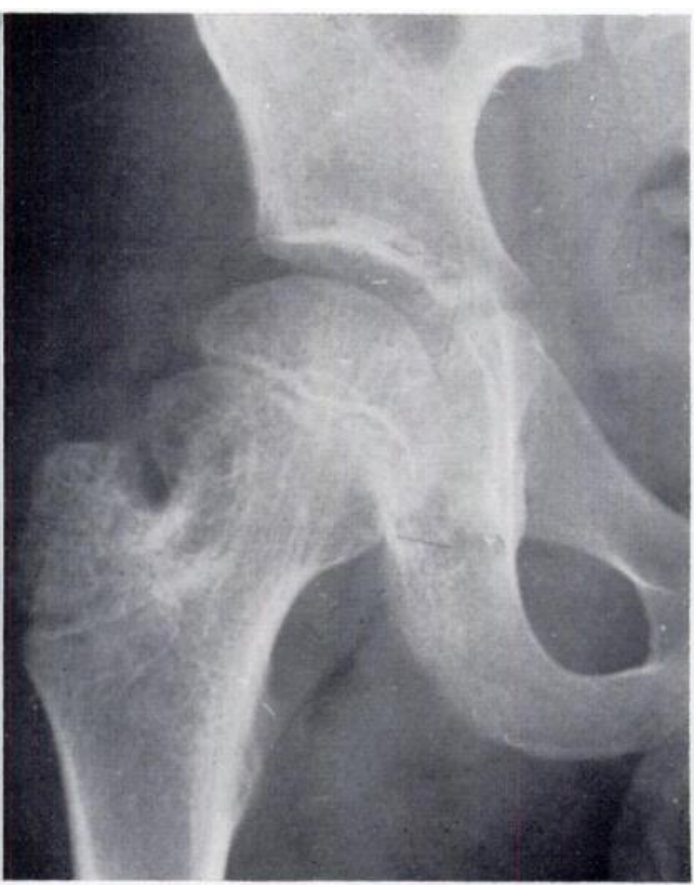

FIG. 11

Case 5. Figure 10-Condition at four months. Figure 11-Condition at nine months: the lesion is healing. 
Case 6-Boy aged three years. He had been investigated nine months before for a left-sided limp; no diagnosis was made. A cold abscess was present a month before his admission. Full movement was present at the left hip. Radiographs revealed a lesion in the distal part of the left femoral neck. He was treated by immediate curettage of the focus through a subtrochanteric approach.

Operation-A large abscess cavity deep to the fascia lata was curetted and was shown to communicate with the focus anteriorly. Sequestra were removed. No bone chips were used. The cavity was dusted with streptomycin and the wound closed.

Progress-Immobilisation in plaster and chemotherapy were continued for three months. Radiographs then showed excellent recalcification and filling in of the cavity. Full movement was present at the hip. Nine months later there was normal function at the hip. Culture of the material from the bone cavity grew tubercle bacilli.

\section{CONCLUSIONS}

A study of these six patients suggests that immediate evacuation of the focus combined with chemotherapy is the satisfactory treatment of this lesion. Radiological evidence of healing, even as early as three months after operation, was most convincing, and compared favourably with the much longer process in the two patients who eventually recovered under conservative treatment.

A lesion which radiologically appears to have come to the surface and to communicate with the joint may not do so (Case 5). The prognosis, even when a lesion communicates with the joint may still be good (Case 4). There is probably a critical interval between infection of a joint cavity from this type of lesion and the stage when hyaline cartilage is irretrievably damaged. Surgery and chemotherapy during this interval can still preserve normal function. Cavities situated in the distal part of the neck can be emptied successfully through a subtrochanteric approach without opening the joint.

In all of the three patients treated by chemotherapy and operation the lesion appeared active and the cavity showed no surrounding sclerosis. The vascularity of these lesions was thought to be important in favouring rapid healing. The patient in Case 3, who never had good movement at any stage, probably had a concomitant synovial involvement of the hip joint.

\section{SUMMARY}

Tuberculosis of the femoral neck is an uncommon lesion occurring in the first decade. In three cases treated by immediate surgery under antibiotic cover excellent results were obtained.

\section{TUBERCULOSIS OF THE TROCHANTERIC BURSA AND GREATER TROCHANTER}

During the seventeen years up to the end of 1956 thirty-two patients suffering from tuberculosis of the gluteal femoral bursa and greater trochanter have been treated in Heatherwood Orthopaedic Hospital. The treatment and results are reviewed.

Chemotherapy has profoundly influenced the treatment and prognosis of this condition. Eighteen of the patients treated during the last seven years of the period under review were subjected to a standardised procedure consisting of radical surgery and chemotherapy. The results are compared with those obtained in the fourteen patients treated earlier, for whom different methods were employed.

There is now an extensive literature on trochanteric tuberculosis. Teale first described the condition as a clinical entity in 1870. Meyerding and Mroz (1933) reported nineteen cases, all proved: two had bursal involvement alone and fourteen had tuberculosis elsewhere. Sinuses persisted in four after radical excision. Wassersug (1940) reported eighteen cases. Two had bursal involvement. Five showed no evidence of tuberculosis elsewhere. Ten of these patients were subjected to radical surgery and in eight the lesion was healed after three years. Alvik (1949) reported thirty-six patients treated between 1936 and 1948 . He believed that the disease spread from bursa to bone, and that the bursa might become infected by

vol. $40 \mathrm{~B}$, No. 3, AUGUST 1958 
TABLE I

Clinical Details in Eighteen Cases of Tuberculosis of the Trochanteric Bursa and Greater Trochanter Treated by The “Standard” Method Described in the Text

\begin{tabular}{|c|c|c|c|c|c|c|c|c|c|}
\hline \multirow{3}{*}{$\begin{array}{c}\text { Case } \\
\text { number }\end{array}$} & \multirow{3}{*}{ Sex } & \multirow{3}{*}{$\begin{array}{c}\text { Age } \\
\text { (years) }\end{array}$} & \multirow{3}{*}{ Side } & \multirow{3}{*}{ History } & \multicolumn{5}{|c|}{ Infection of bursa alone } \\
\hline & & & & & \multicolumn{2}{|c|}{ Other lesions } & \multirow[b]{2}{*}{ Result } & \multirow{2}{*}{$\begin{array}{l}\text { Confirmatory } \\
\text { findings }\end{array}$} & \multirow[b]{2}{*}{ Comment } \\
\hline & & & & & Site & \begin{tabular}{|} 
Time \\
relationship
\end{tabular} & & & \\
\hline 7 & $\mathbf{F}$ & 42 & $\mathbf{L}$ & $\begin{array}{l}\text { Swelling and } \\
\text { tenderness } \\
6 \text { months }\end{array}$ & Lung & Before & $\begin{array}{l}\text { Healed } \\
1 \frac{1}{2} \text { years }\end{array}$ & Pus TB + ve & $\begin{array}{l}\text { Only case with } \\
\text { early bursal } \\
\text { involvement }\end{array}$ \\
\hline 8 & $\mathbf{M}$ & 39 & $\mathbf{R}$ & $\begin{array}{l}\text { Small superficial } \\
\text { abscess } 1 \text { month }\end{array}$ & $\begin{array}{l}\text { Lumbar } \\
\text { spine }\end{array}$ & Before & $\begin{array}{c}\text { Healed } \\
3 \frac{1}{2} \text { years }\end{array}$ & Histology + ve & - \\
\hline 9 & $\mathbf{M}$ & 21 & $\mathbf{L}$ & $\begin{array}{l}\text { Small superficial } \\
\text { abscess } 1 \text { month }\end{array}$ & $\begin{array}{l}\text { Left } \\
\text { knee }\end{array}$ & Before & $\begin{array}{c}\text { Healed } \\
3 \frac{3}{4} \text { years }\end{array}$ & Histology + ve & - \\
\hline 10 & $\mathrm{~F}$ & 67 & $\mathbf{L}$ & $\begin{array}{l}\text { Aching and stiff- } \\
\text { ness } 6 \text { months. } \\
\text { Superficial } \\
\text { abscess } 1 \text { month }\end{array}$ & - & - & $\begin{array}{l}\text { Healed } \\
2 \text { years }\end{array}$ & Histology + ve & - \\
\hline 11 & $\mathbf{M}$ & 24 & $\mathbf{L}$ & $\begin{array}{l}\text { Slight discomfort } \\
7 \text { years. Swelling } \\
3 \text { years: } \\
\text { abscess incised: } \\
\text { sinus } 3 \text { months }\end{array}$ & - & - & $\begin{array}{l}\text { Healed } \\
1 \frac{1}{4} \text { years }\end{array}$ & Pus TB + ve & $\begin{array}{l}\text { Grossly thickened } \\
\text { and diseased } \\
\text { bursa }\end{array}$ \\
\hline 12 & $\mathbf{M}$ & 20 & $\mathbf{L}$ & $\begin{array}{c}\text { Sinus } 8 \text { years } \\
\text { before. Healed: } \\
\text { reformed } 5 \text { months }\end{array}$ & Lung & Before & $\begin{array}{l}\text { Healed } \\
2 \text { years }\end{array}$ & Pus TB +ve & - \\
\hline 13 & $\mathbf{M}$ & 25 & $\mathbf{L}$ & \begin{tabular}{|} 
Discomfort \\
$2 \frac{1}{2}$ years. \\
Abscess 5 months
\end{tabular} & Lung & Before & $\begin{array}{l}\text { Healed } \\
6 \ddagger \text { years }\end{array}$ & $\begin{array}{c}\text { Histology } \\
\text { TB + ve } \\
\text { Guinea pig + ve }\end{array}$ & - \\
\hline 14 & $\mathbf{M}$ & 56 & $\mathbf{R}$ & $\begin{array}{c}\text { Sinus } 5 \text { years } \\
\text { before. Healed: } \\
\text { reformed } 3 \text { months }\end{array}$ & $\begin{array}{l}\text { Lumbar } \\
\text { spine }\end{array}$ & Before & $\begin{array}{l}\text { Healed } \\
3 \uparrow \text { years }\end{array}$ & Histology + ve & - \\
\hline \multicolumn{10}{|c|}{ Infection of bursa and trochanter } \\
\hline 15 & $\mathbf{M}$ & 37 & $\mathbf{R}$ & $\begin{array}{l}\text { Recurrent sinus } \\
\text { formation } \\
18 \text { years: } \\
4 \text { unsuccessful } \\
\text { operations }\end{array}$ & - & - & $\begin{array}{l}\text { Healed } \\
2 \frac{1}{2} \text { years }\end{array}$ & Pus TB + ve & $\begin{array}{l}\text { Cavitation and } \\
\text { sequestration post- } \\
\text { laterally involving } \\
\text { extra-capsular } \\
\text { femoral neck }\end{array}$ \\
\hline 16 & $\mathbf{M}$ & 75 & $\mathbf{L}$ & $\begin{array}{c}\text { Persistent sinus } \\
\text { formation since } \\
\text { childhood. Several } \\
\text { unsuccessful } \\
\text { operations }\end{array}$ & $\underset{\text { hipht }}{\text { Right }}$ & Before & $\begin{array}{l}\text { Healed } \\
3 \text { years }\end{array}$ & - & - \\
\hline 17 & $\mathbf{M}$ & 47 & L & $\begin{array}{l}\text { Recurrent sinus } \\
\text { formation } \\
38 \text { years: } \\
2 \text { unsuccessful } \\
\text { operations }\end{array}$ & Lung & Before & $\begin{array}{c}\text { Healed } \\
3 \frac{1}{2} \text { years }\end{array}$ & - & $\begin{array}{l}\text { Extensive cavita- } \\
\text { tion post-laterally } \\
\text { involving extra- } \\
\text { capsular femoral } \\
\text { neck. Massive } \\
\text { sequestration }\end{array}$ \\
\hline 18 & $\mathbf{M}$ & 28 & $\mathbf{L}$ & $\begin{array}{l}\text { Discomfort } 7 \\
\text { years. "Cyst" } \\
\text { excised } 5 \text { years. } \\
\text { Abscess incised: } \\
\text { sinus } 3 \text { months }\end{array}$ & - & - & $\begin{array}{l}\text { Healed } \\
4 \frac{3}{4} \text { years }\end{array}$ & Pus TB + ve & $\begin{array}{l}\text { Grossly thickened } \\
\text { bursa and slight } \\
\text { bone destruction }\end{array}$ \\
\hline 19 & $\mathbf{F}$ & 19 & $\mathbf{R}$ & Sinus 14 months & - & - & $\begin{array}{l}\text { Healed } \\
3 \frac{1}{2} \text { years }\end{array}$ & $\begin{array}{l}\text { Histology } \\
\text { TB + ve }\end{array}$ & - \\
\hline
\end{tabular}


TABLE I-continued

\begin{tabular}{|c|c|c|c|c|c|c|c|c|c|}
\hline \multicolumn{10}{|c|}{ Infection of bursa and trochanter-continued } \\
\hline $\begin{array}{c}\text { Case } \\
\text { number }\end{array}$ & Sex & $\begin{array}{c}\text { Age } \\
\text { (years) }\end{array}$ & Side & History & Site & $\begin{array}{c}\text { Time } \\
\text { relationship }\end{array}$ & Result & $\begin{array}{l}\text { Confirmatory } \\
\text { findings }\end{array}$ & Comment \\
\hline 20 & $\mathbf{M}$ & 26 & $\mathbf{L}$ & $\begin{array}{l}\text { Mass explored } \\
9 \text { months before: } \\
\text { sinus } 3 \text { months }\end{array}$ & - & - & $\begin{array}{l}\text { Healed } \\
3 \frac{3}{4} \text { years }\end{array}$ & $\begin{array}{l}\text { Histology } \\
\text { TB + ve. } \\
\text { Culture } \\
\text { TB + ve }\end{array}$ & $\begin{array}{l}\text { Re-explored after } \\
3 \text { years for local- } \\
\text { ised tenderness } \\
\text { and thickening. } \\
\text { Small active focus } \\
\text { in remnant of } \\
\text { bursa due to } \\
\text { inadequate } \\
\text { excision at } \\
\text { primary operation }\end{array}$ \\
\hline 21 & $\mathbf{F}$ & 32 & $\mathbf{L}$ & $\begin{array}{l}\text { Sinus } 14 \text { years } \\
\text { before; healed } \\
\text { with conservative } \\
\text { treatment. Re- } \\
\text { curred } 4 \text { months }\end{array}$ & - & - & $\begin{array}{l}\text { Healed } \\
5 \text { years }\end{array}$ & - & - \\
\hline 22 & $\mathbf{M}$ & 33 & $\mathbf{R}$ & $\begin{array}{l}\text { Sinus } 4 \text { years } \\
\text { before: healed on } \\
\text { conservative } \\
\text { treatment: } \\
\text { recurred } 5 \text { months }\end{array}$ & - & - & $\begin{array}{l}\text { Healed } \\
6 \frac{1}{2} \text { years }\end{array}$ & - & - \\
\hline 23 & $\mathbf{F}$ & 14 & $\mathbf{R}$ & $\begin{array}{r}\text { Concomitant } \\
\text { trochanter and } \mathrm{h} \\
\text { Healed on } 21 \mathrm{mo} \\
\text { treatment. S }\end{array}$ & $\begin{array}{l}\text { esions } \\
\text { ip } 6 \text { ye } \\
\text { nths' } \\
\text { nus } 3\end{array}$ & $\begin{array}{l}\text { of right } \\
\text { ars before. } \\
\text { onservative } \\
\text { months }\end{array}$ & $\begin{array}{l}\text { Healed } \\
3 \text { years. } \\
\text { Sinus } \\
\text { recurred }\end{array}$ & - & $\begin{array}{l}\text { Extensive ramifica } \\
\text { tions of sinus } \\
\text { around hip joint. } \\
\text { Primary lesion } \\
\text { uncertain }\end{array}$ \\
\hline 24 & $\mathbf{M}$ & 28 & $\mathbf{L}$ & $\begin{array}{r}\text { Sinus } 3 \text { years be } \\
\text { trochanter } 2 \\
\text { Involvemen } \\
\text { subluxation w } \\
\text { of op }\end{array}$ & $\begin{array}{l}\text { ore. } \\
\text { ears b } \\
\text { tof hi } \\
\text { thin } 2 \\
\text { ration }\end{array}$ & $\begin{array}{l}\text { Excision of } \\
\text { efore. } \\
\text { p and } \\
\text { months }\end{array}$ & $\begin{array}{c}\text { Healed } \\
7 \text { months } \\
\text { after } \\
\text { operation. } \\
\text { Healed } \\
7 \text { years }\end{array}$ & - & $\begin{array}{l}\text { Heavy secondary } \\
\text { infection. } \\
\text { Eventual bony } \\
\text { fusion of hip }\end{array}$ \\
\hline
\end{tabular}

"gravitational abscesses" from tuberculosis of the lumbar spine. Thirty-two of his thirty-six patients had other tuberculous lesions before the bursal infection. Seven out of eight patients who had previously had tuberculosis of the spine had gravitational abscesses on the same side. Lampe (1953) reported seventeen cases. All the patients had abscesses and sixteen had sinuses and thirteen had past and present evidence of tuberculosis elsewhere. He believed that the lesion probably started in the bony trochanter because of the presence of encysted foci in nine cases. He obtained good results in thirteen cases and believed that radical surgery combined with antibiotics was the treatment of choice. Lindahl (1952) reported thirty-five cases of trochanteric tuberculosis. Radiographic changes were noted in twenty-five. He classified his results under four headings: eleven patients were treated by immobilisation in plaster and minor surgery (group 1); twelve by radical incision with primary suture (group 2); ten patients by radical excision and antibiotics (group 3); and two by antibiotics alone (group 4). Reactivation occurred in four cases in the first and second groups, but in none in the third or fourth group; the follow-up periods of these two latter groups were, however, short. McNeur and Pritchard (1955) reported thirty-eight cases of trochanteric tuberculosis treated at the Royal National Orthopaedic Hospital during twenty-five years. Their impressions were that the osteitis was of considerable duration and possibly preceded the bursal involvement. 
TABLE II

Clinical Details in Fourteen Cases of Tuberculosis of the Trochanteric Bursa and Greater Trochanter Treated Otherwise than by the “ Standard ” Method Described in the Text

\begin{tabular}{|c|c|c|c|c|c|c|c|c|}
\hline \multirow{2}{*}{$\begin{array}{c}\text { Case } \\
\text { number }\end{array}$} & \multirow{2}{*}{ Sex } & \multirow{2}{*}{$\begin{array}{l}\text { Age } \\
\text { (years) }\end{array}$} & \multirow{2}{*}{ Side } & \multirow{2}{*}{ History } & \multicolumn{2}{|c|}{ Other lesions } & \multirow{2}{*}{ Treatment } & \multirow{2}{*}{ Comment } \\
\hline & & & & & Site & $\begin{array}{c}\text { Time } \\
\text { relationship }\end{array}$ & & \\
\hline 25 & $\mathbf{M}$ & 42 & $\mathbf{R}$ & $\begin{array}{l}\text { Erosion of troch- } \\
\text { anter noted } 23 \\
\text { years before. } \\
\text { Large abscess } \\
\text { several months }\end{array}$ & $\begin{array}{l}\text { Right } \\
\text { ischio-pubic } \\
\text { ramus }\end{array}$ & Concomitant & $\begin{array}{l}\text { Excision of } \\
\text { abscess; } \\
\text { excision of } \\
\text { trochanter; } \\
\text { chemotherapy }\end{array}$ & $\begin{array}{l}\text { Involvement of } \\
\text { hip } 15 \text { months } \\
\text { later }\end{array}$ \\
\hline 26 & $\mathbf{F}$ & 37 & $\mathbf{L}$ & $\begin{array}{l}\text { Pain } 5 \text { years. Sinus } \\
4 \text { years. Total } \\
\text { excision of troch- } \\
\text { anter } 2 \frac{1}{2} \text { years. } \\
\text { Involvement of hip } \\
\text { within } 1 \text { month }\end{array}$ & - & - & $\begin{array}{l}\text { Drainage of } \\
\text { large cavity in } \\
\text { trochanter and } \\
\text { upper femoral } \\
\text { region; penicillin }\end{array}$ & $\begin{array}{c}\text { Heavy secondary } \\
\text { infection. } \\
\text { Discharge much } \\
\text { less but sinuses } \\
\text { persisted } 5 \\
\text { years. } \\
\text { Healed } 4 \frac{1}{2} \text { years. } \\
\text { Eventual bony } \\
\text { fusion at hip } \\
\text { joint }\end{array}$ \\
\hline 27 & $\mathbf{M}$ & 48 & $\mathbf{R}$ & $\begin{array}{l}\text { Recurrent sinus } \\
\text { formation } 20 \text { years. } \\
2 \text { unsuccessful } \\
\text { operations }\end{array}$ & - & - & $\begin{array}{l}\text { Removal of } \\
\text { sequestrum; } \\
\text { no chemotherapy }\end{array}$ & $\begin{array}{l}\text { Sinus persisted } \\
3 \text { years. } \\
\text { Healed } 6 \text { years }\end{array}$ \\
\hline 28 & $\mathbf{M}$ & 13 & $\mathbf{R}$ & $\begin{array}{l}\text { Pain and stiffness } \\
\text { left hip } 3 \text { years. } \\
13 \text { months' con- } \\
\text { servative treatment } \\
\text { both lesions. } \\
\text { Sinus formation } \\
7 \text { months }\end{array}$ & Pubis & Concomitant & $\begin{array}{l}\text { Total excision } \\
\text { of trochanter }\end{array}$ & $\begin{array}{l}\text { Healed } 2 \text { years. } \\
\text { No later } \\
\text { examination }\end{array}$ \\
\hline 29 & $\mathbf{M}$ & 23 & L & $\begin{array}{c}\text { Recurrent sinuses } \\
6 \text { years: } \\
2 \text { unsuccessful } \\
\text { operations }\end{array}$ & - & - & Sequestrectomy & $\begin{array}{l}\text { Sinuses healed, } \\
\text { but involvement } \\
\text { left hip } \\
5 \text { years later }\end{array}$ \\
\hline 30 & $\mathbf{M}$ & 49 & $\mathbf{R}$ & $\begin{array}{c}\text { Recurrent abscesses } \\
\text { and sinuses } 26 \text { years: } \\
1 \text { unsuccessful } \\
\text { operation }\end{array}$ & - & - & $\begin{array}{l}\text { Curettage and } \\
\text { chemotherapy }\end{array}$ & $\begin{array}{l}\text { Not healed: } \\
\text { further surgery } \\
\text { refused by } \\
\text { patient }\end{array}$ \\
\hline 31 & $\mathbf{M}$ & 57 & $\mathbf{L}$ & $\begin{array}{l}\text { Sinus for } \\
\text { many years }\end{array}$ & $\begin{array}{l}\text { Lung. } \\
\text { Spine }\end{array}$ & Before & $\begin{array}{l}\text { Curettage and } \\
\text { chemotherapy }\end{array}$ & $\begin{array}{c}\text { Healed } 17 \text { months. } \\
\text { Sinus re-formed. } \\
\text { Further surgery } \\
\text { refused }\end{array}$ \\
\hline 32 & $\mathbf{F}$ & 65 & $\mathbf{R}$ & $\begin{array}{l}\text { Abscesses and } \\
\text { sinuses } 33 \text { years: } \\
\text { healed after } \\
\text { operation. } \\
\text { Abscess } 2 \frac{1}{2} \text { years }\end{array}$ & $\begin{array}{l}\text { Right } \\
\text { elbow }\end{array}$ & $\begin{array}{l}3 \text { years } \\
\text { before }\end{array}$ & $\begin{array}{l}\text { Curettage and } \\
\text { chemotherapy }\end{array}$ & $\begin{array}{l}\text { Healed } 3 \text { years. } \\
\text { Patient died } \\
\text { from unspecified } \\
\text { illness }\end{array}$ \\
\hline 33 & $\mathbf{F}$ & 46 & $\mathbf{L}$ & $\begin{array}{l}\text { Recurrent sinuses } \\
33 \text { years. Several } \\
\text { periods of con- } \\
\text { servative treatment: } \\
1 \text { unsuccessful } \\
\text { operation }\end{array}$ & 一 & - & $\begin{array}{l}\text { Chemotherapy } \\
\text { only; } \\
\text { surgery refused }\end{array}$ & Failed to heal \\
\hline 34 & $\mathbf{M}$ & 28 & $\mathbf{R}$ & $\begin{array}{l}\text { Abscesses and } \\
\text { sinuses } 4 \text { years. } \\
\text { Healed for } 1 \text { year } \\
\text { with conservative } \\
\text { treatment: sinus re- } \\
\text { curred } 2 \text { months }\end{array}$ & 一 & 一 & Sequestrectomy & $\begin{array}{l}\text { Failed to heal. } \\
\text { Follow-up } \\
\text { only } 1 \text { year }\end{array}$ \\
\hline
\end{tabular}

THE JOURNAL OF BONE AND JOINT SURGERY 
TABLE II-continued

\begin{tabular}{|c|c|c|c|c|c|c|c|c|}
\hline \multirow{2}{*}{$\begin{array}{c}\text { Case } \\
\text { number }\end{array}$} & \multirow{2}{*}{ Sex } & \multirow{2}{*}{$\begin{array}{l}\text { Age } \\
\text { (years) }\end{array}$} & \multirow{2}{*}{ Side } & \multirow{2}{*}{ History } & \multicolumn{2}{|c|}{ Other lesions } & \multirow{2}{*}{ Treatment } & \multirow{2}{*}{ Comment } \\
\hline & & & & & Site & $\begin{array}{l}\text { Time } \\
\text { relationship }\end{array}$ & & \\
\hline 35 & $\mathbf{M}$ & 23 & $\mathbf{R}$ & $\begin{array}{l}\text { Recurrent sinuses } \\
1 \text { year: } 4 \text { periods } \\
\text { of conservative } \\
\text { treatment; several } \\
\text { minor operations }\end{array}$ & - & - & $\begin{array}{l}\text { Rest in bed } \\
2 \text { months }\end{array}$ & Failed to heal \\
\hline 36 & $\mathbf{M}$ & 47 & $\mathbf{L}$ & $\begin{array}{l}\text { Fall on trochanter } \\
5 \text { months before. } \\
\text { Sinus } 3 \text { months }\end{array}$ & - & - & $\begin{array}{l}\text { Healed on } \\
\text { admission. } \\
\text { No treatment }\end{array}$ & Healed $2 \frac{1}{2}$ years \\
\hline 37 & $\mathbf{M}$ & 56 & $\mathbf{L}$ & $\begin{array}{l}\text { Abscess } 16 \text { years } \\
\text { before. Responded } \\
\text { to conservative } \\
\text { treatment plus } \\
\text { several operations }\end{array}$ & $\begin{array}{l}\text { Lung. } \\
\text { Spine }\end{array}$ & Before & No treatment & Healed 15 years \\
\hline 38 & $\mathbf{M}$ & 11 & $\mathbf{R}$ & $\begin{array}{l}\text { Pain right hip } \\
\text { after kick } \\
11 \text { months before }\end{array}$ & - & - & $\begin{array}{l}\text { Conservative } \\
\text { treatment for } \\
\text { lesion of } \\
\text { trochanter } \\
4 \text { years. } \\
\text { No abscess } \\
\text { or sinus }\end{array}$ & $\begin{array}{l}\text { Re-formation of } \\
\text { trochanteric epi- } \\
\text { physis with coxa } \\
\text { valga and } \frac{1}{2} \text {-inch } \\
\text { lengthening. The } \\
\text { only example of a } \\
\text { primary endosteal } \\
\text { process. Healed } \\
\text { at } 9 \text { months. No } \\
\text { later examination }\end{array}$ \\
\hline
\end{tabular}

Twenty-five of the thirty-eight patients had tuberculosis elsewhere-this preceded the trochanteric lesion in seventeen, was concomitant with it in five, and occurred later in three. The results obtained in the earlier cases treated by immobilisation and minor surgical procedures were disappointing, and they suggested that early disease might respond favourably to aspiration of abscesses, combined with antibiotic therapy.

\section{CLINICAL MATERIAL AND METHODS OF TREATMENT}

The standard treatment adopted for the eighteen patients of whom details are supplied in Table I was as follows. Chemotherapy was begun on the morning of operation or some days before. All patients received streptomycin, usually combined with para-amino-salicylic acid (PAS) or izo-nicotinic acid hydrazide (INH) or both. At operation a liberal exposure of the greater trochanter was obtained by a long vertical incision of the fascia lata. It was often found necessary to use a transverse incision as well to excise an extensively diseased and adherent bursa. A thorough inspection of the front and back of the trochanter, as well as the extra-capsular part of the femoral neck behind, can also be carried out through this exposure. Total excision of the greater trochanter was regarded as unnecessary and dangerous, and intact bone was not removed except when necessary to drain an infected deep track in bone. After a thorough debridement the entire area was dusted with streptomycin and the wound closed in layers. Nothing more than a firm hip spica dressing was applied until the removal of sutures two weeks later. Chemotherapy was continued for six to twelve weeks and thereafter full activity was allowed. Illustrative radiographs are shown in Figures 12 to 19.

Details of the remaining fourteen patients, twelve of whom received some other form of treatment, are given in Table II. The follow-up in many of these cases has been incomplete, but enough information is available to show that the results have been unsatisfactory. The results in the whole series are shown in Table III.

vol. $40 \mathrm{~B}$, No. 3, AUGUST 1958 


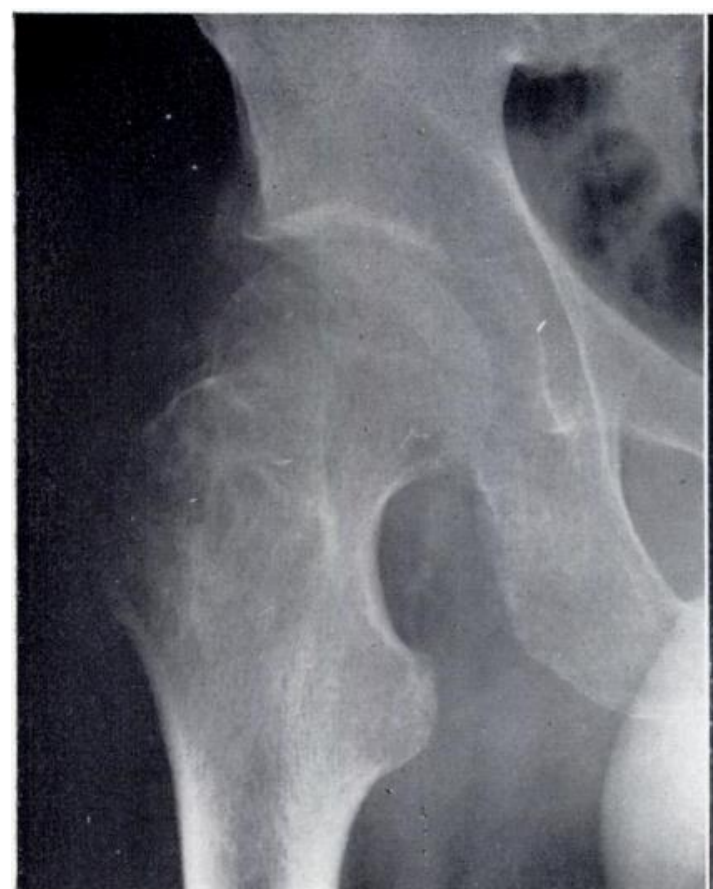

FIG. 12

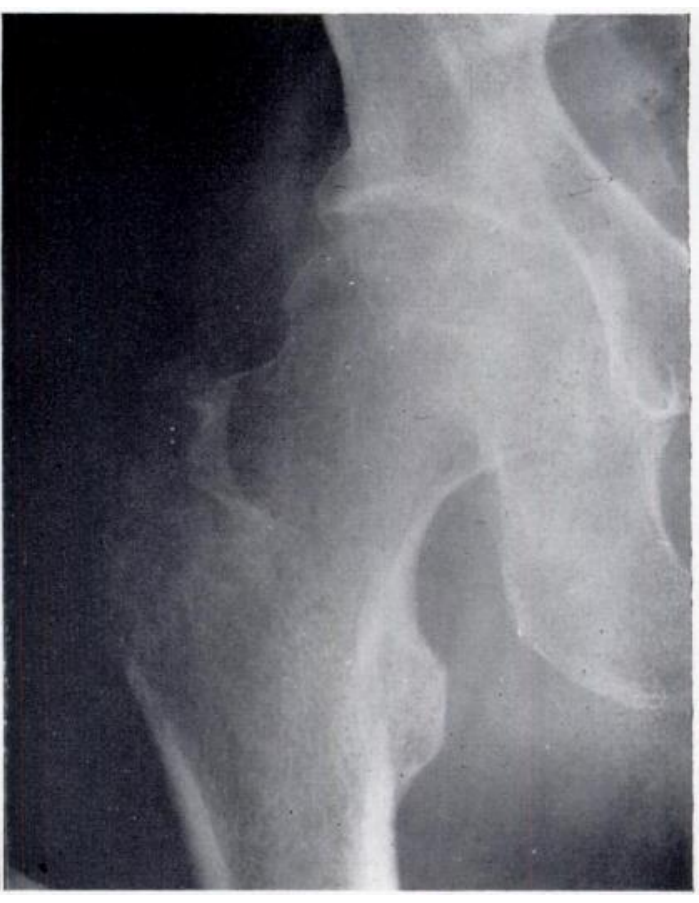

Fig. 13

Case 15. Figure 12-Radiograph with the hip in full lateral rotation. Figure 13-Radiograph with the hip in full medial rotation. (The erosion extended to the extra-capsular part of the femoral neck.

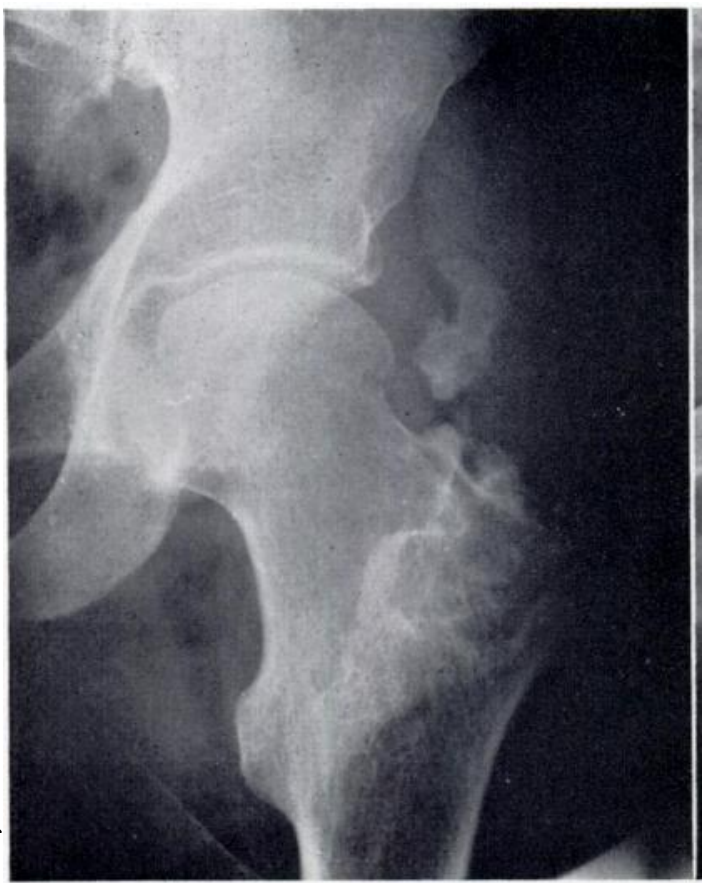

Fig. 14

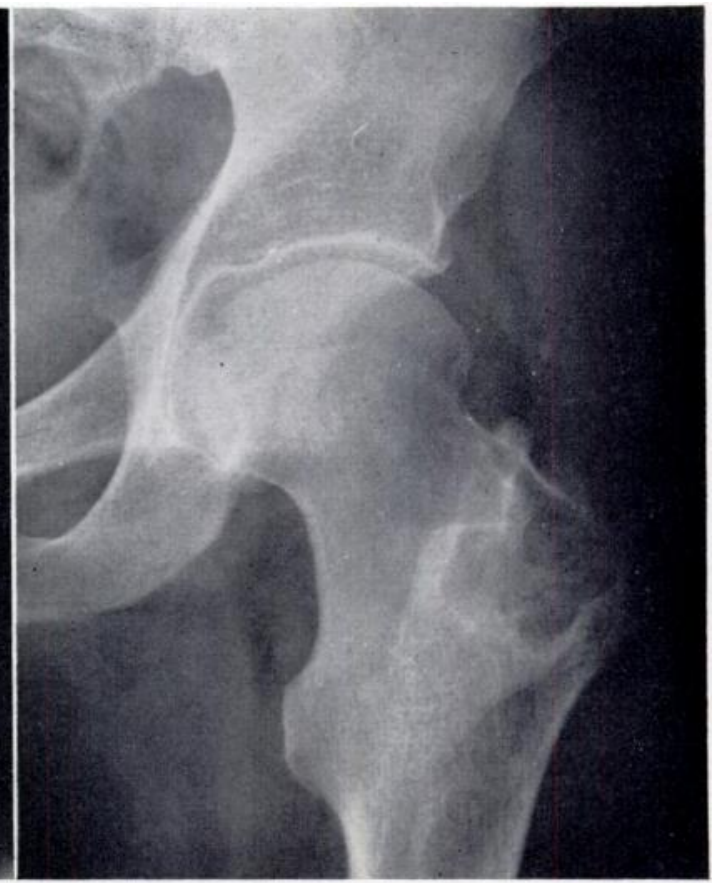

Fig. 15

Case 17. Figure 14-Massive sequestrum in a large cavity on postero-lateral aspect of the trochanter, with smaller sequestrum in the soft tissues above. Figure 15-Appearance after operation. (The erosion extended to the extra-capsular part of the femoral neck.) 


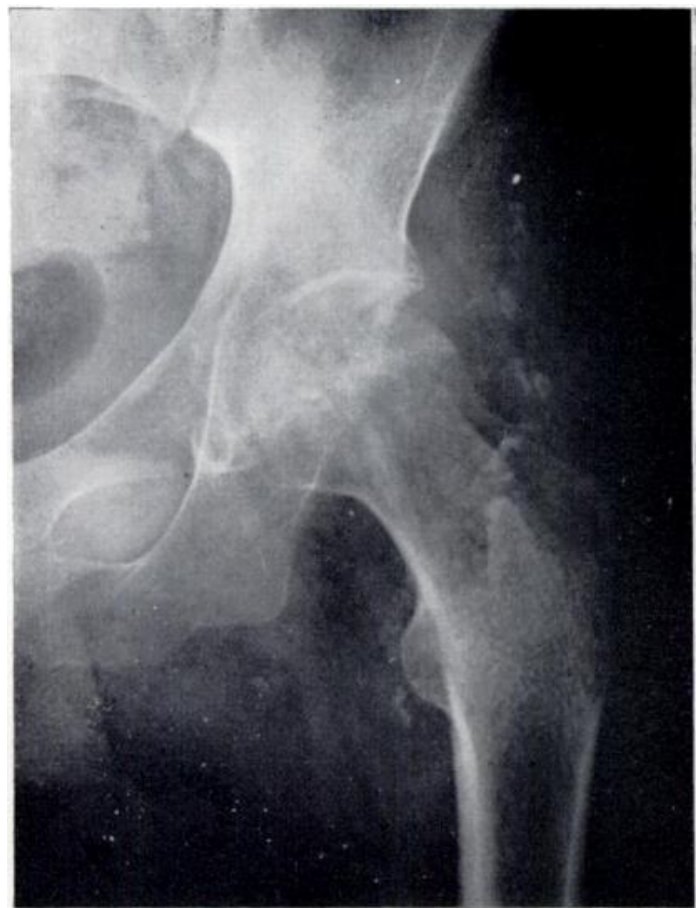

FIG. 16

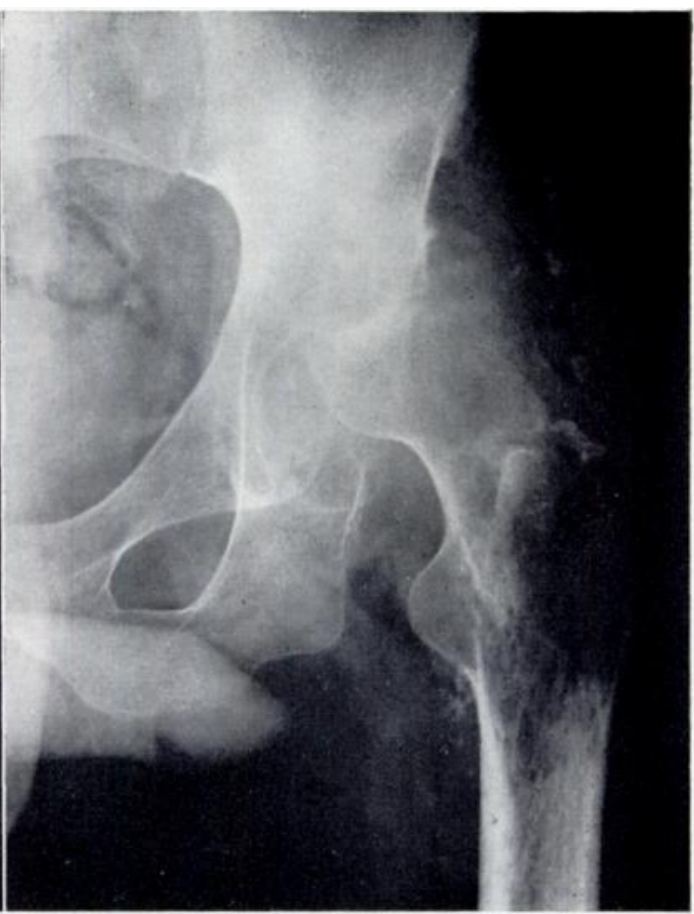

FIG. 17

Case 24. Figure 16-Radiograph showing early involvement of the hip joint after excision of the greater trochanter, with several small sequestra in the soft tissues. Figure 17-One year later. Further destruction of the femoral head and subluxation of the joint.

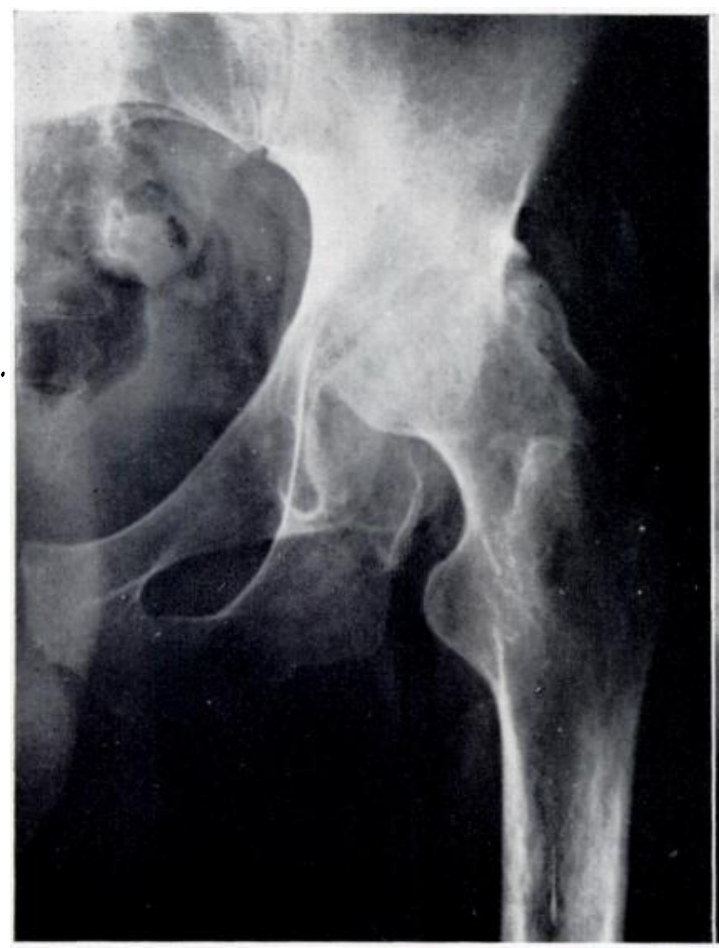

FIG. 18

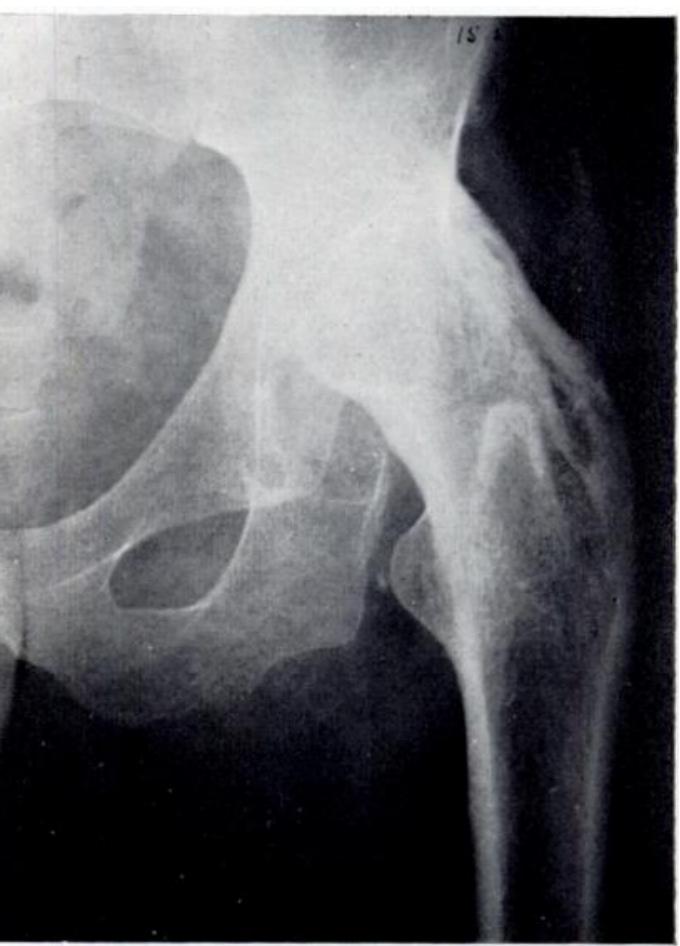

Fig. 19

Case 24. Figure 18-A year later still (four months after operation). Reossification is taking place. Figure 19Bony fusion two years after operation.

VOL. 40 B, NO. 3, AUgUST 1958 


\section{COMMENT}

Case 7 was the only one in which there was early bursal involvement. The bursal sac was thin walled, contained a little serous fluid and was excised without difficulty. The remaining seven patients in the group with bursal infection alone showed marked chronic changes, especially Case 11. When bone destruction was present it was unusual to find a grossly diseased bursa. Case 18 was an exception, but in that case the erosion was slight and probably early.

Bone destruction was most marked on the postero-lateral aspect of the trochanter, and in Cases 15 and 17 there was erosion of the extra-capsular part of the femoral neck (Fig. 14). It was thought that the disease might spread to the hip joint by this route.

The patient in Case 23, who six years before had had a concomitant lesion of the right hip and trochanter, made an excellent recovery from the hip disease and retained full movement. The subsequent excision was not regarded as entirely adequate because the sinus track ramified extensively about the hip. It was not established which lesion was the source of the suppuration.

In Cases 24 (Fig. 16) and 26 the hip joint was already involved when the patients were admitted, and total excision of the trochanter had been performed previously without chemotherapy. Case 25 showed involvement of the hip joint fifteen months after excision of

TABLE III

Results in Thirty Cases of Tuberculosis of the Greater Trochanter

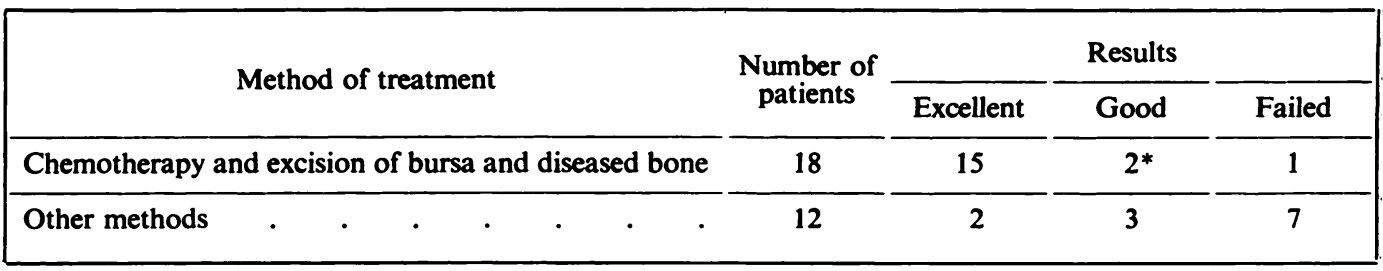

* One patient required further exploration.

(Excellent $=$ First intention and permanent healing with no further symptoms. Good $=$ Decreased suppuration and later permanent healing. Failed =Persistent sinuses, later sinus formation or spread of disease to hip joint.)

the trochanter and chemotherapy. Spread of the disease from a concomitant lesion in the ischio-pubic ramus could not, however, be ruled out in this case.

In Case 29 the lesion healed after a sequestrectomy without chemotherapy. The hip joint was involved five years later.

Case 38 was the only one in which the primary lesion was thought to be osseous. Central cavitation was present, and complete re-formation of the trochanter took place under a prolonged course of conservative treatment. There was no abscess or sinus formation throughout, but the patient had some coxa valga with half an inch of lengthening. The etiology was not proved and the follow-up was of only nine months.

CONCLUSIONS

1. The disease is very chronic and advice is sought for superficial abscess of sinus formation. While the disease remains deep to the fascia lata it is often silent or causes only minor symptoms. Time might profitably be spent in palpating the trochanteric region in the after-care of all tuberculous patients, as the thickened bursa is easily recognisable.

2. The evidence is overwhelmingly in favour of spread of the disease from bursa to bone. Eight cases out of the eighteen reviewed in Table I showed bursal involvement alone: in the remaining ten cases every degree of bone destruction from the slightest surface erosion to extensive cavitation was noted.

3. The disease probably spreads as a surface infection, although in a few cases the presence of large sequestra suggests an infection in depth at the same time. In all patients with bone 
destruction the area of disease was well demarcated and a uniform hard surface of bone presented after removal of sequestra and tuberculous debris. In view of this, excision of the trochanter appears to be superfluous and possibly dangerous, even in the presence of antibiotics. 4. Radiography is an unreliable guide; decalcified sequestra and debris are often not shown. Some useful information may, however, be gained by radiographs in full medial and lateral rotation (Figs. 12 and 13).

5. In the absence of gross secondary infection the amount of discharge may be a rough but useful guide to the amount of dead tissue present.

\section{SUMMARY}

The results obtained from combined chemotherapy and radical surgery in eighteen patients with trochanteric tuberculosis have been satisfactory so far, although the period of observation is still short. The results compare very favourably with those of all other methods of treatment.

I should like to express my grateful thanks to Mr G. P. Arden, Mr W. Herschell, Mr Roy H. Maudsley and Mr F. G. Ward for their helpful suggestions in preparing this paper and for their permission to publish Cases 14, 19, 25 and 33; and to Mr Charles Gray for his permission to publish Case 6.

\section{REFERENCES}

AlviK, I. (1949): Tuberculosis of the Greater Trochanter. Acta Orthopaedica Scandinavica, 19, 247. Bergman, K. (1930): Tuberculosis of the Neck of the Femur. Acta Orthopaedica Scandinavica, 1, 281. Cholmeley, J. A. (1939): The Distribution and Treatment of Extra-articular Foci in Tuberculous Arthritis of the Hip-Joint. British Journal of Surgery, 27, 224.

Dobson, J. (1951): Prognosis in Tuberculosis of the Hip. Journal of Bone and Joint Surgery, 33-B, 149.

Hatcher, C. H., and Phemister, D. B. (1937): The Primary Point of Infection in Tuberculosis of the Hip Joint. Surgery, Gynecology and Obstetrics, 65, 721.

LAMPE, C. E. (1953): Tuberculous Osteomyelitis of the Greater Trochanter. Acta Orthopaedica Scandinavica, 22, 307.

LindaHL, O. (1952): Tuberculous Trochanteritis. Acta Tuberculosea Scandinavica, 26, 289.

Logroscino, D. (1936): Inflammatory Localized Lesions of the Juxta-epiphyseal Zone of the Neck of the Femur. Journal of Bone and Joint Surgery, 18, 671.

McNeur, J. C., and Pritchard, A. E. (1955): Tuberculosis of the Greater Trochanter. Journal of Bone and Joint Surgery, 37-B, 246.

Meyerding, H. W., and Mroz, R. J. (1933): Tuberculosis of the Greater Trochanter. Journal of the American Medical Association, 101, 1,308.

PonsetI, I. (1948): Evolution and Treatment of Tuberculosis of the Hip. Surgery, Gynecology and Obstetrics, 87, 257.

Teale, T. P. (1870): On the Simulation of Hip Disease by Suppuration of the Bursa over the Trochanter Major. Lancet, ii, 506.

WASSERSUG, J. D. (1940): Tuberculosis of the Greater Trochanter and Trochanteric Bursae. Journal of Bone and Joint Surgery, 22, 1,075.

Wilkinson, M. C. (1953): Synovectomy and Curettage in the Treatment of Tuberculosis of Joints. Journal of Bone and Joint Surgery, 35-B, 209. 